\title{
A Porous Coordination Polymer Based on Bipyridinium Carboxylate Linkers with High and Reversible Ammonia Uptake
}

Maxime Leroux, ${ }^{\dagger}$ Nicolas Mercier, ${ }^{*}{ }^{\dagger}$ Magali Allain, ${ }^{\dagger}$ Marie-Claire Dul, ${ }^{\dagger}$ Jens Dittmer, ${ }^{\gamma}$ Abdel Hadi Kassiba, ${ }^{\gamma}$ Jean-Pierre Bellat, ${ }^{\S}$ Guy Weber ${ }^{\S}$ and Igor Bezverkhyy ${ }^{* \S}$

${ }^{\dagger}$ MOLTECH Anjou, UMR-CNRS 620o, Université d'Angers, 2 Bd Lavoisier, 49045 Angers, France

${ }^{\gamma}$ IMMM, UMR-CNRS 6283, Université du Maine, Avenue O. Messiaen, 72085 Le Mans, France

${ }^{\S}$ ICB, UMR-CNRS 6303, Université de Bourgogne-Franche Comté, 9 A. Savary, 21078 Dijon, France

\section{Supporting Information}

\section{A-Synthesis}

A1- Procedure for the preparation of ligand:

First step: synthesis of 1,1'-bis-(2,4-Dinitrophenyl)-4,4'-bipyridinium dichloride ((DNP)Cl $\left.{ }_{2}\right)$<smiles>O=[N+]([O-])c1ccc(-[n+]2ccc(-c3cc[n+](-c4ccc([N+](=O)[O-])cc4[N+](=O)[O-])cc3)cc2)c([N+](=O)[O-])c1</smiles>

The mixture of 4,4'-bipyridine $(6.20 \mathrm{~g}, 36 \mathrm{mmol})$ and 2,4-dinitrochlorobenzene $(17.0 \mathrm{~g}, 84 \mathrm{mmol})$ in $70 \mathrm{~mL}$ of ethanol (aq. EtOH, $96 \%$ ) is refluxed for $24 \mathrm{~h}$. After cooling to room temperature, precipitation is filtered and dried under vacuum. $13.3 \mathrm{~g}(60 \%)$ of pale-green powder is obtained.

$\mathrm{RMN}^{1} \mathrm{H}\left(300 \mathrm{MHz}, \mathrm{D}_{2} \mathrm{O}, \mathrm{ppm}\right): \delta=9.52(\mathrm{~d}, 4 \mathrm{H}, \mathrm{J}=9.0 \mathrm{~Hz}, \mathrm{ArH}), 9.45(\mathrm{~d}, 2 \mathrm{H}, \mathrm{J}=3.0 \mathrm{~Hz}, \mathrm{ArH}), 9.00$ $(\mathrm{d}, 2 \mathrm{H}, \mathrm{J}=3.0 \mathrm{~Hz}, \operatorname{ArH}), 8.97$ (d, 4H, J = 9.0 Hz, ArH), 8.34 (d, 2H, J = 9.0 Hz, ArH).

Second step: synthesis of 4,4'-bis(carboxyphenyl)-bipyridinium dichloride dihydrate $\left(\mathrm{H}_{2} p c 1 \mathrm{Cl}_{2} \cdot \mathbf{2} \mathrm{H}_{2} \mathrm{O}\right)$<smiles></smiles>

$$
\mathrm{M}=469.4 \mathrm{~g} / \mathrm{mol}
$$

To $4 \mathrm{~g}$ ( $8.5 \mathrm{mmol})$ of 1,1'-bis-(2,4-Dinitrophenyl)-4,4'-bipyridinium dichloride $\left((\mathrm{DNP})_{2} \mathrm{Cl}\right)$ in $150 \mathrm{~mL}$ of ethanol (aq. EtOH, $96 \%$ ), $2.34 \mathrm{~g}(17.1 \mathrm{mmol})$ of 4 -aminobenzoic acid is added. The mixture is 
stirred together at $80{ }^{\circ} \mathrm{C}$ during $24 \mathrm{~h}$, then cooled to room temperature. The brown/purple mixture obtained is filtered, washed with ethanol, diethyl ether and dried under vacuum. Finally, $2.68 \mathrm{~g}(80 \%)$ of the final product as a purple powder, is obtained.

RMN ${ }^{1} \mathrm{H}\left(300 \mathrm{MHz}, \mathrm{D}_{2} \mathrm{O}, \mathrm{ppm}\right): \delta=9.48(\mathrm{~d}, 4 \mathrm{H}, \mathrm{J}=6.0 \mathrm{~Hz}, 4$ arom H), $8.84(\mathrm{~d}, 4 \mathrm{H}, \mathrm{J}=6.0 \mathrm{~Hz}, 4$ arom $\mathrm{H}), 8.34$ (d, 4H, J = 9.0 Hz, vio), 7.96 (d, 4H, J = 9.0 Hz, vio).

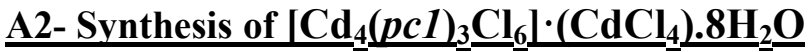

A mixture of $\mathrm{H}_{2} \mathrm{pclCl}_{2} 2 \mathrm{H}_{2} \mathrm{O}(25.3 \mathrm{mg}, 0.05 \mathrm{mmol}), \mathrm{CdCl}_{2}(73.3 \mathrm{mg}, 0.4 \mathrm{mmol}), \mathrm{DMF}(2 \mathrm{~mL})$, Dioxane $(2 \mathrm{~mL}), \mathrm{H}_{2} \mathrm{O}(0.5 \mathrm{~mL})$ was heated at $100{ }^{\circ} \mathrm{C}$ for $48 \mathrm{~h}$ in a $25 \mathrm{~mL}$ Teflon-lined stainless steel autoclave. After the mixture was cooled slowly to room temperature at a rate of $2{ }^{\circ} \mathrm{C} / \mathrm{h}$. Crystals suitable for X-ray analyses were collected, washed with ethyl acetate and air-dried.

\section{B-Crystal data}

\section{$\underline{C d}_{4}(p c 1)_{3} \underline{C l}_{6} \perp \cdot\left(\mathrm{CdCl}_{4}\right): 8 \mathrm{H}_{2} \underline{\mathrm{O}-\text { Summary of crystallographic data }}$}

Table S1. Crystal data and structure refinement for $\left[\mathrm{Cd}_{4}(p c 1)_{3} \mathrm{Cl}_{6}\right] \cdot\left(\mathrm{CdCl}_{4}\right) \cdot 8 \mathrm{H}_{2} \mathrm{O}$.

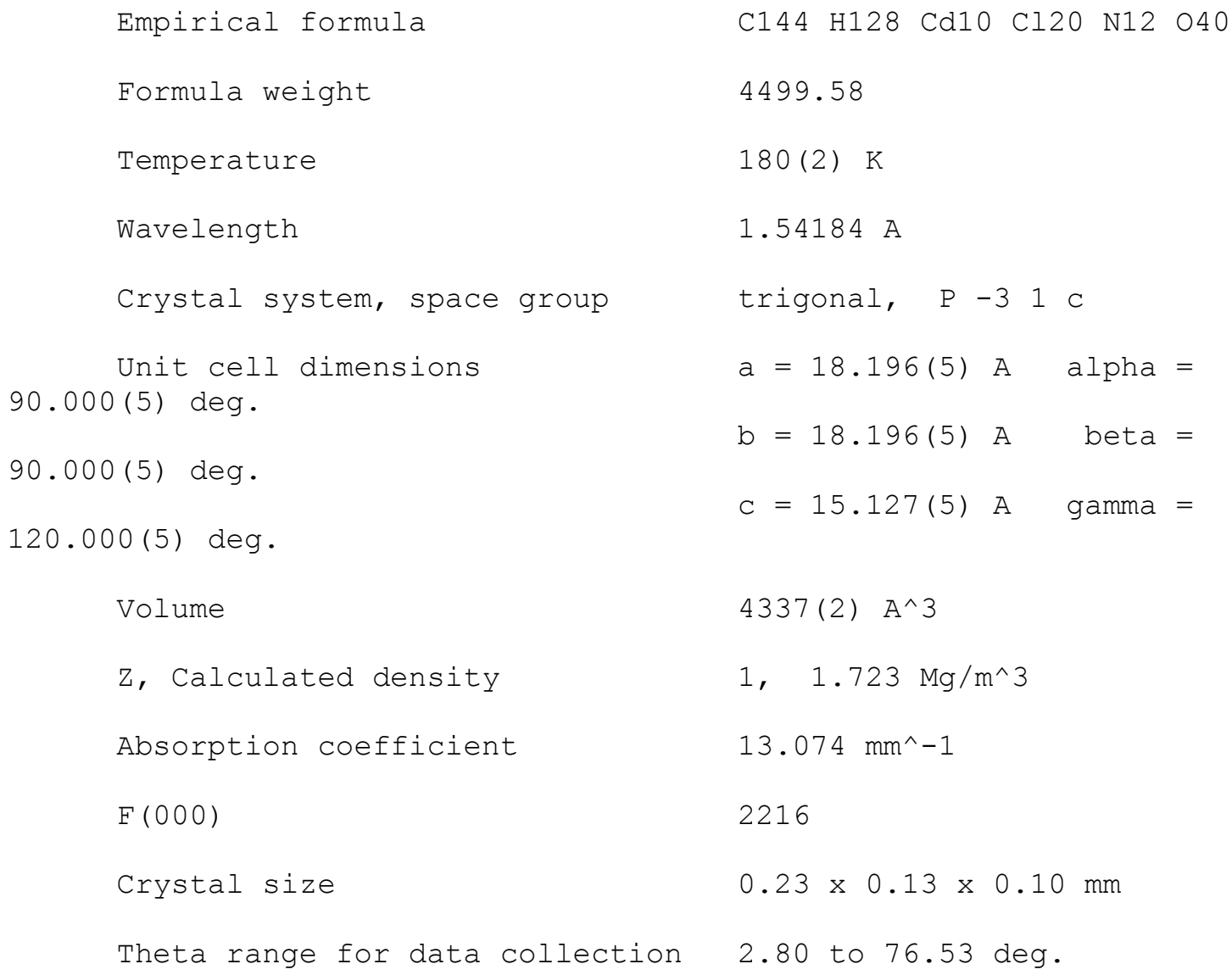




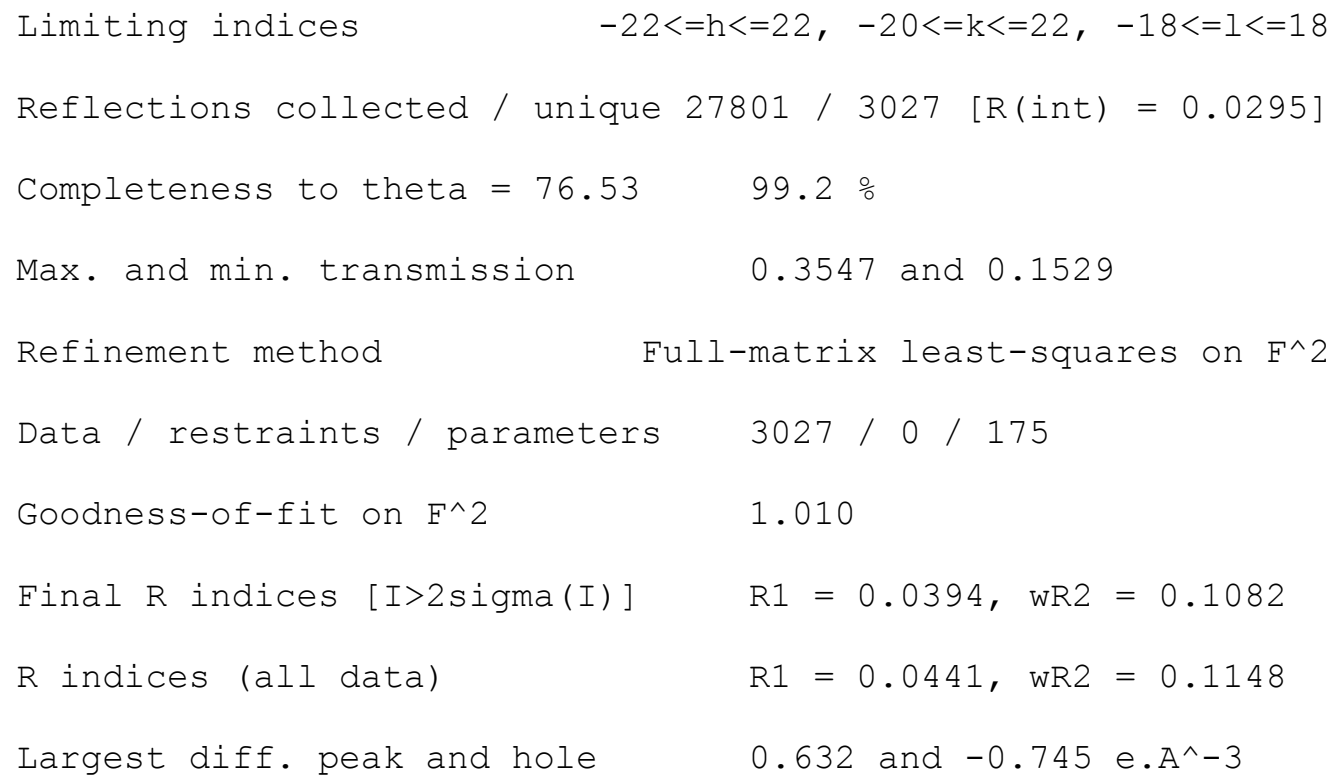

\section{C-X-Ray powder Diffraction}

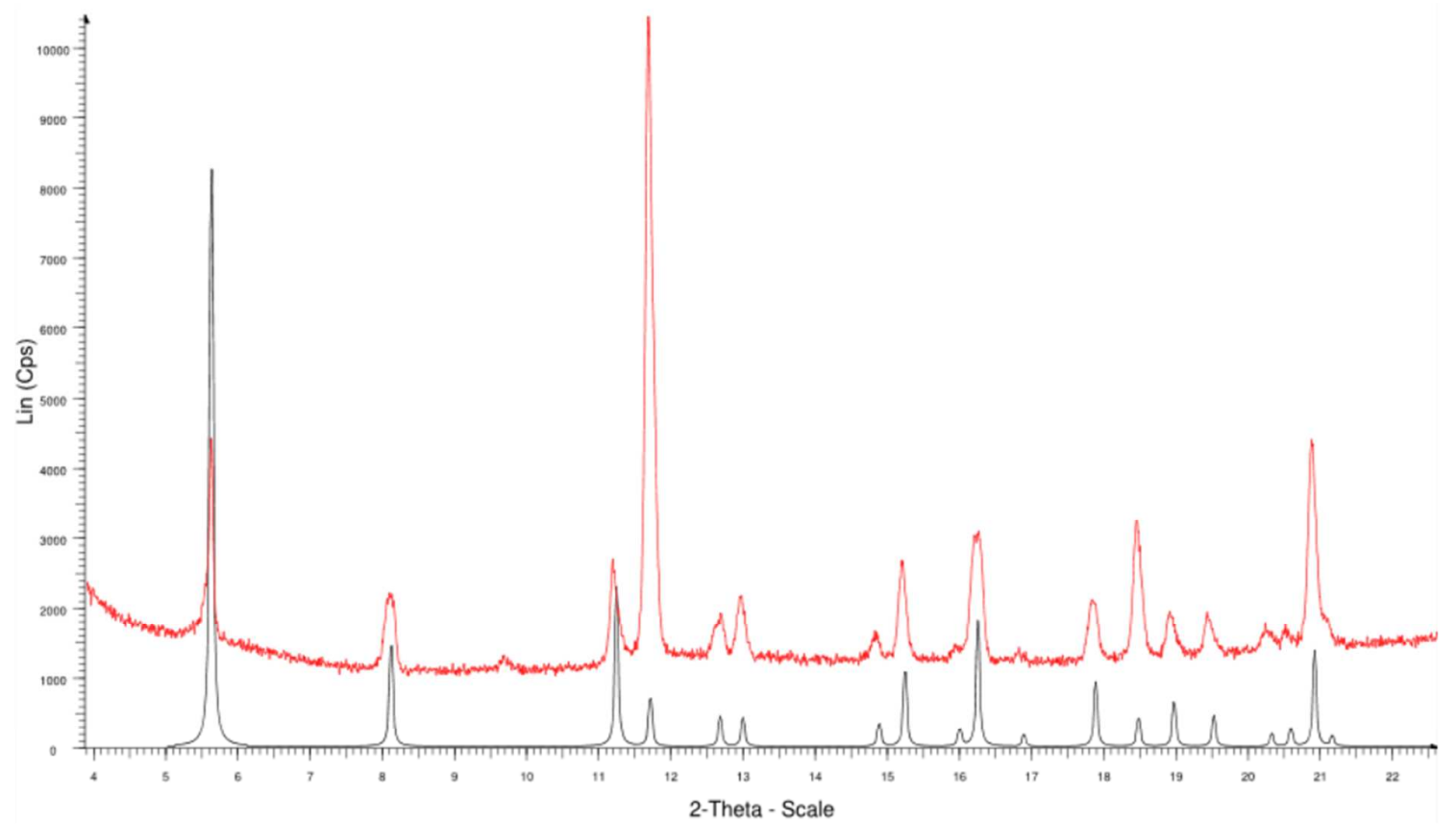

Fig. S1: theoretical (black) and experimental (red) X-ray powder diffraction patterns of $\left[\mathrm{Cd}_{4}(p c 1)_{3} \mathrm{Cl}_{6}\right] \cdot\left(\mathrm{CdCl}_{4}\right) \cdot 8 \mathrm{H}_{2} \mathrm{O}$ at room temperature 


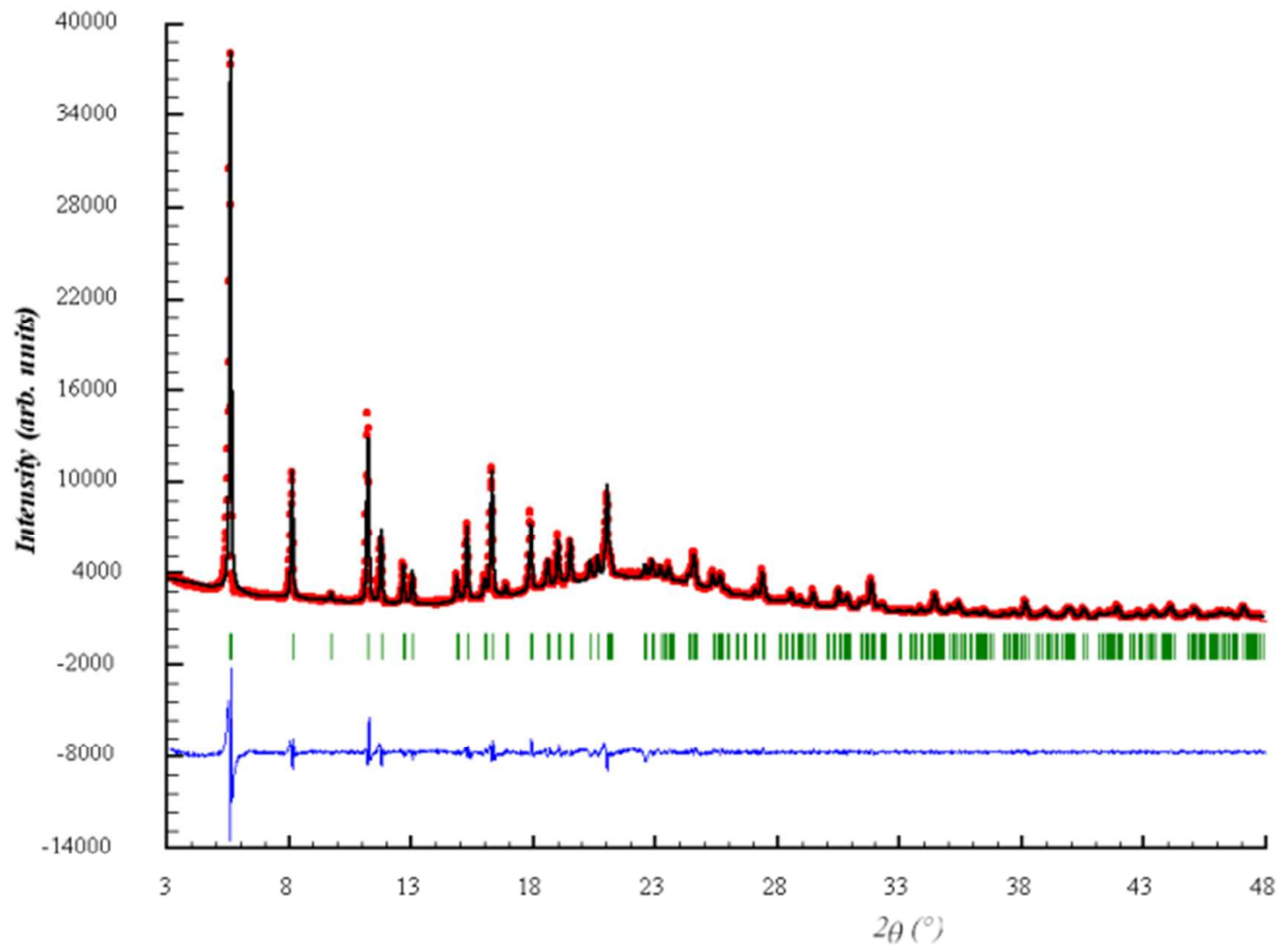

Fig. S2: Le Bail full profile refinement of the dehydrated compound $\left[\mathrm{Cd}_{4}(p c 1)_{3} \mathrm{Cl}_{6}\right] \cdot\left(\mathrm{CdCl}_{4}\right)$ in the P-31c space group with unit cell parameters $(a=b=18.175 \AA$ and $c=15.012 \AA$ -room temperature-) close to those of the initial sample measured in air ( $a=b=$ $18.196 \AA$ and $c=15.127 \AA-180 \mathrm{~K}-)$. 


\section{D- TGA}

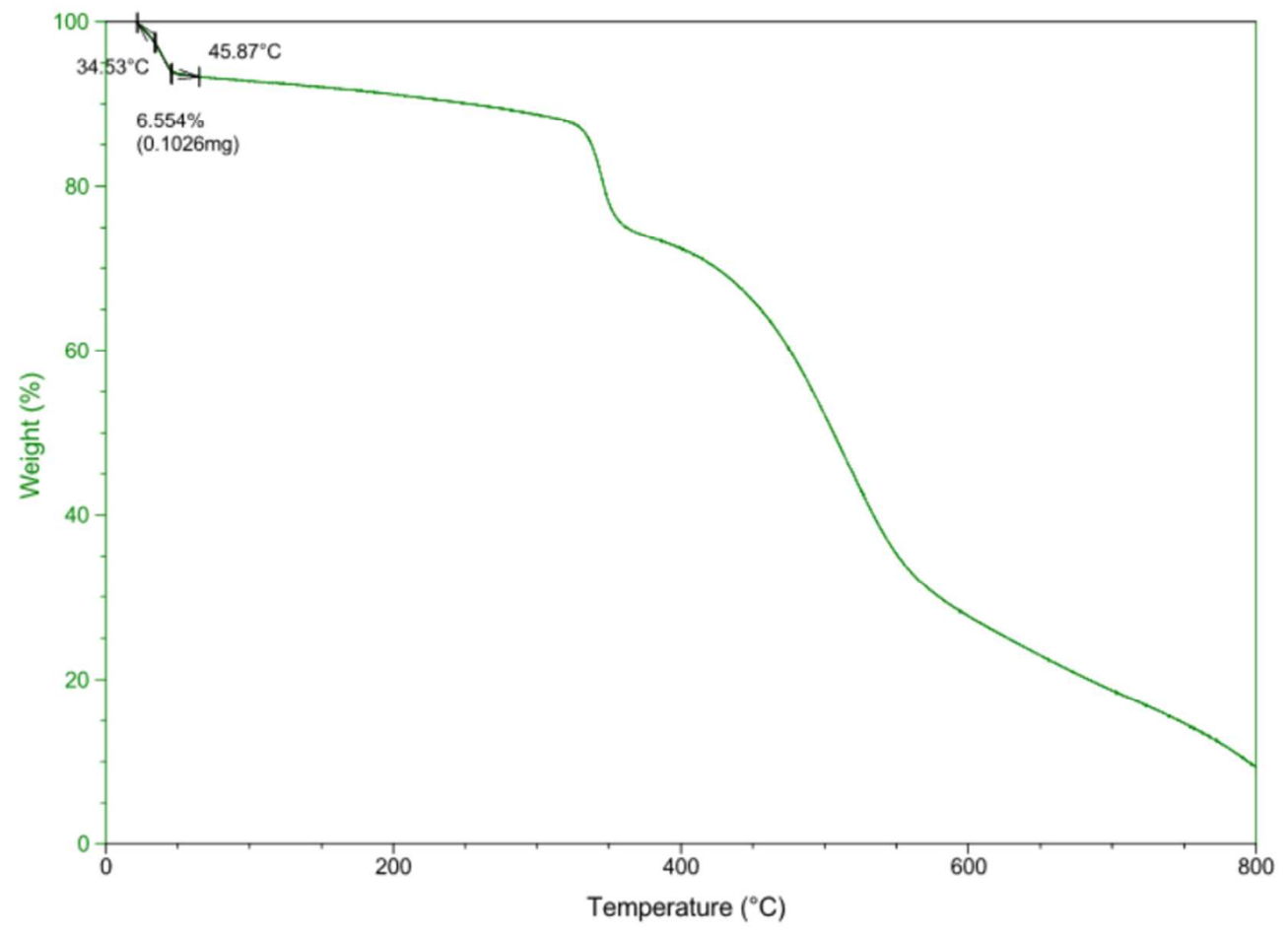

Fig. S3: TGA analysis of $\left[\mathrm{Cd}_{4}(p c 1)_{3} \mathrm{Cl}_{6}\right] \cdot\left(\mathrm{CdCl}_{4}\right) \cdot 8 \mathrm{H}_{2} \mathrm{O}$ compound. Weight loss of $8 \mathrm{H}_{2} \mathrm{O}$ : calculated $6.40 \%$ / exp. $6.554 \%$.

\section{$\underline{\text { E- Solid state UV/Vis spectroscopy }}$}

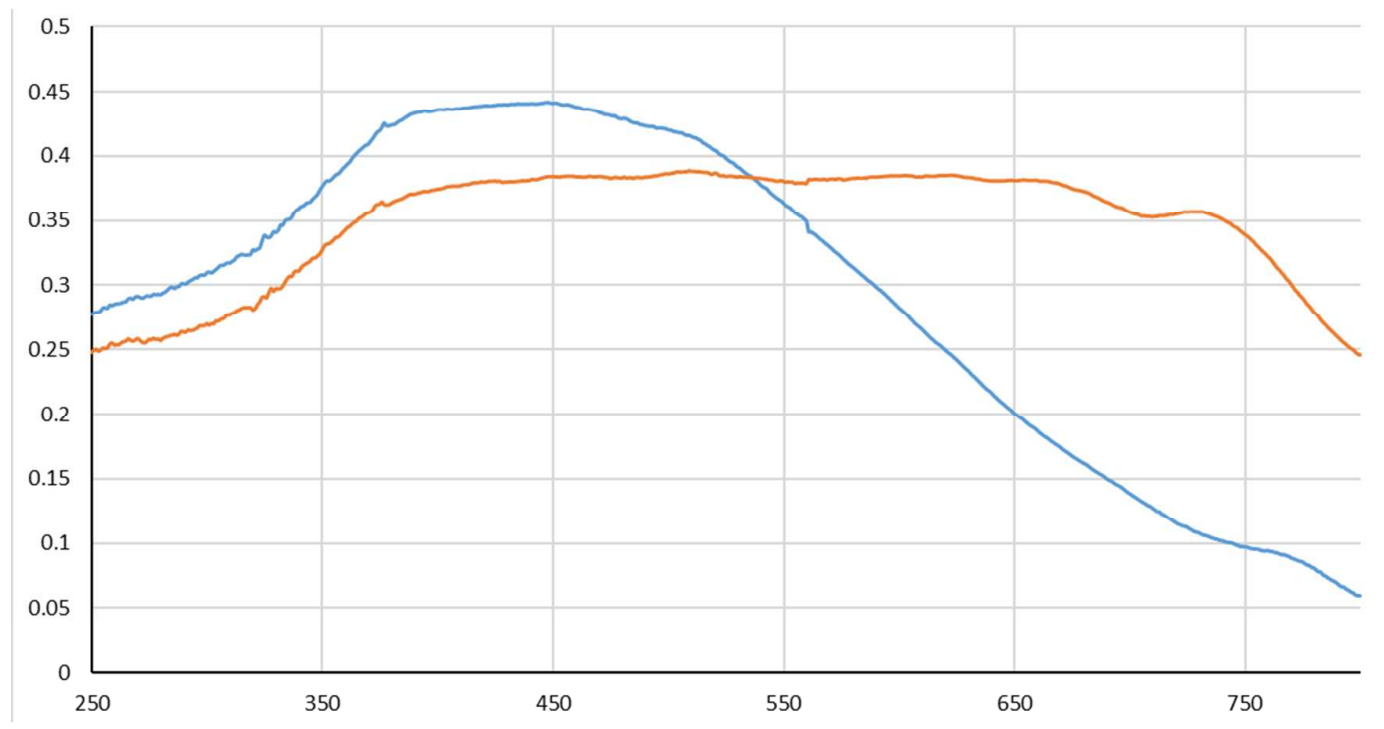

Fig. S4: UV-Vis spectra of the as-synthesized $\left[\mathrm{Cd}_{4}(p c 1)_{3} \mathrm{Cl}_{6}\right] \cdot\left(\mathrm{CdCl}_{4}\right) \cdot 8 \mathrm{H}_{2} \mathrm{O}$ compound (blue), and the dehydrated phase after exposure to ammonia (orange). 


\section{F- IR spectroscopy}

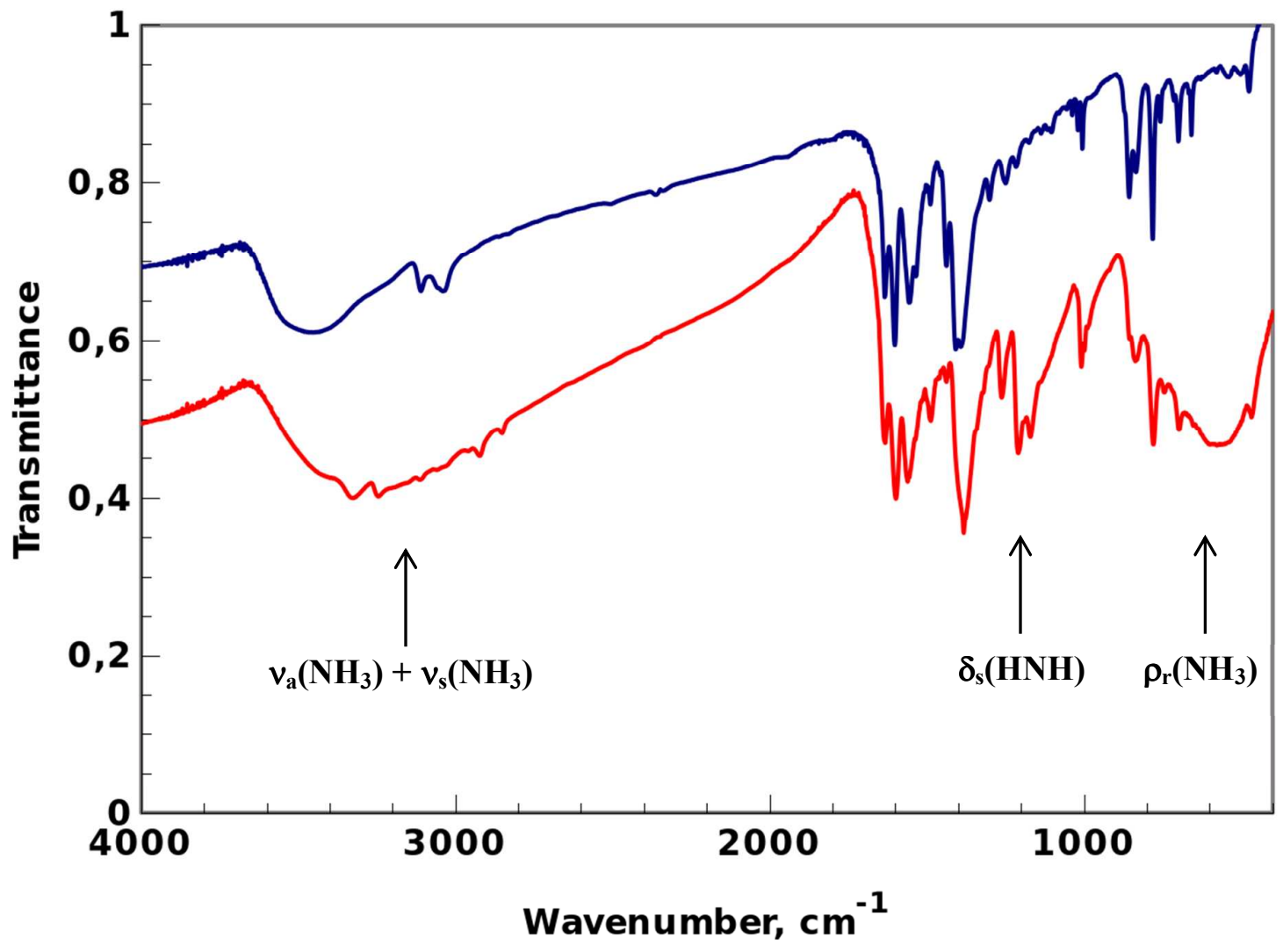

Fig. S5 FTIR spectra of initial 1 (blue) and of the sample containing $8.2 \mathrm{mmol} / \mathrm{g}$ of ammonia (red). Specific bands which are indicative of the existence of ammonia are shown. 


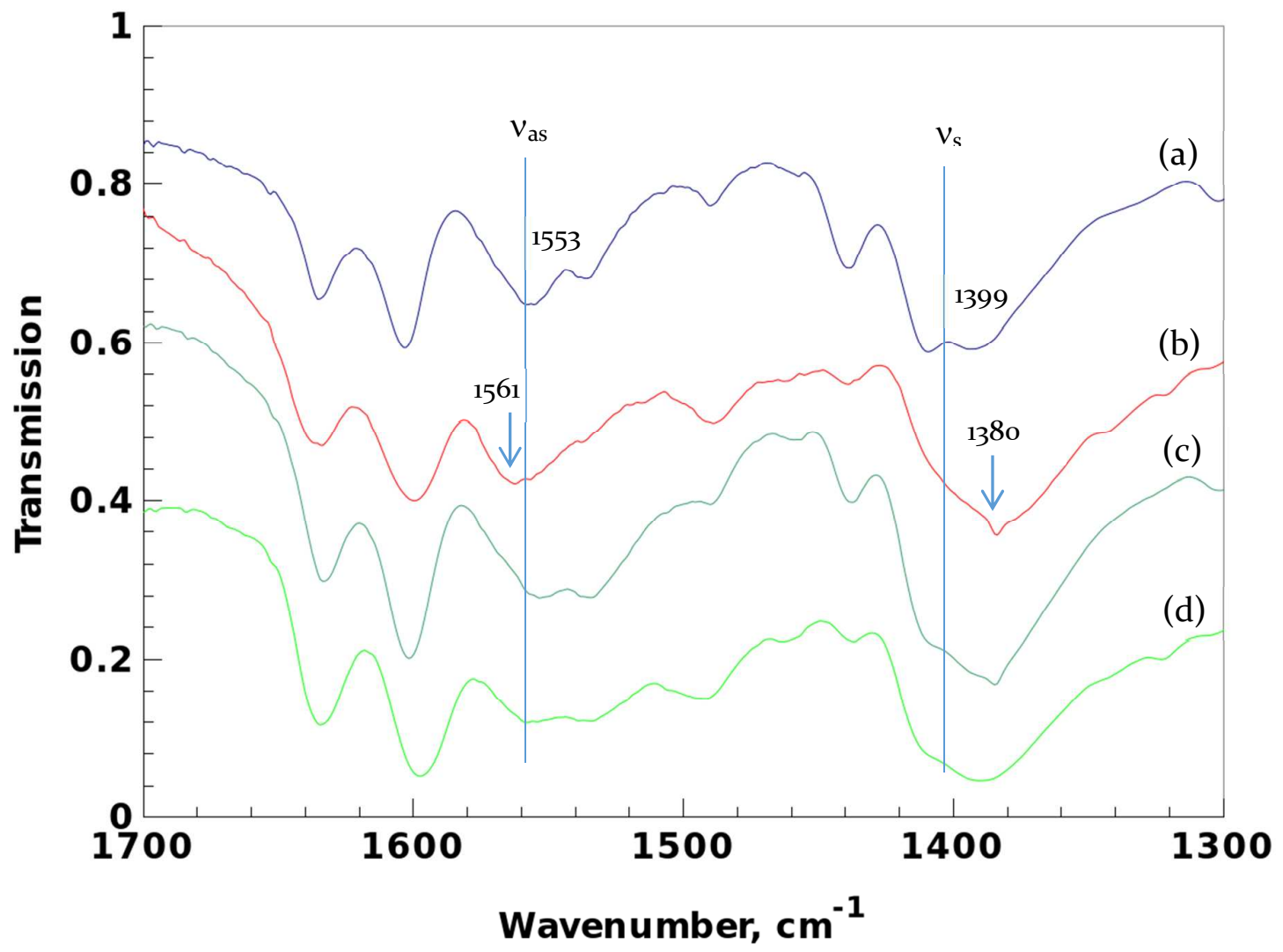

Fig. S6 FTIR spectra in $1300-1700 \mathrm{~cm}^{-1}$ range of different samples: (a) initial 1, (b) the sample containing $8.2 \mathrm{mmol} / \mathrm{g}$ of ammonia, (c) solid regenerated at $473 \mathrm{~K}$ after 1 cycle of adsorption-desorption of $\mathrm{NH}_{3}$, (d) regenerated solid after 3 cycles. The stretching bands of carboxylates are indicated. 


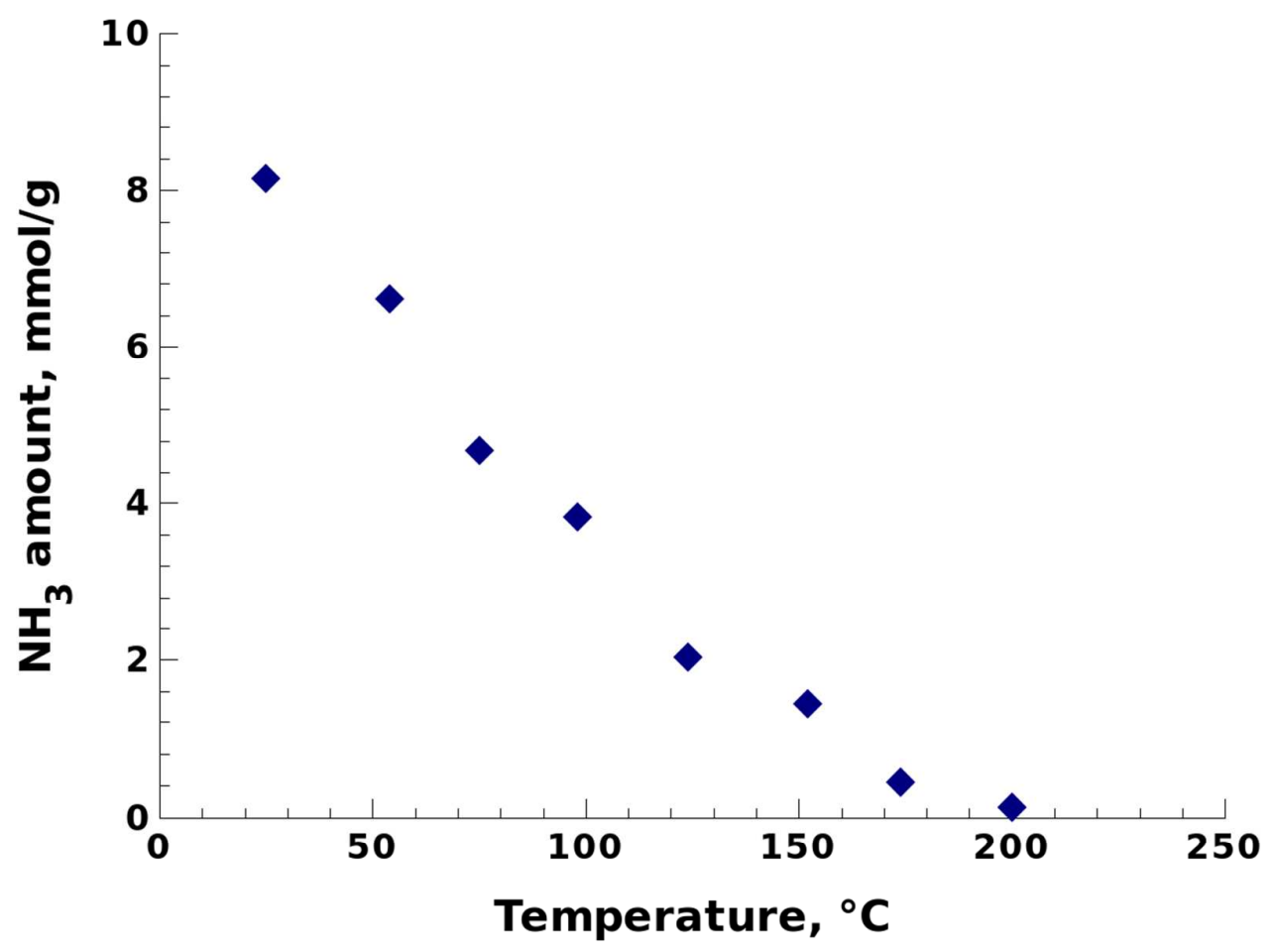

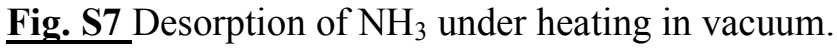

